\title{
Effect of Cynodon dactylon community on the conservation and reinforcement of riparian shallow soil in the Three Gorges Reservoir area
}

\author{
Fangqing Chen*, Jinxia Zhang, Miao Zhang and Jianzhu Wang
}

\begin{abstract}
Introduction: Riparian vegetation plays a crucial role in soil conservation and riverbank reinforcement. The Three Gorges hydrologic project has significantly changed the pattern of water-level fluctuation and riparian environment, which significantly influenced plant community development and its effect on soil conservation and riverbank protection. Cynodon dactylon, a perennial grass with developed root system and creeping stems, has become a dominant riparian species in the Three Gorges area after the completion of the dam. We aimed to characterize how the soil-root system under the $C$. dactylon community responded to environmental changes and effects of the soil-root system on shallow soil conservation and riverbank reinforcement through field investigation and laboratory test.

Methods: We conducted a field survey and experimental research. Quadrates of a natural C. dactylon community were set up on a riverbank along an altitude gradient. Plants were sampled randomly for the measurements of spatial structure and tensile strength of roots. Soil erosion resistance, soil scour resistance, and shear strength of sampled soil-root systems and control soil were tested in the laboratory.
\end{abstract}

Results: Roots of the $C$. dactylon community significantly increased soil erosion resistance, soil scour resistance, and shear strength, enhancing the stability of shallow soil and riverbank. Due to water-level fluctuation, C. dactylon at lower altitudes was subjected to less time exposed to air. As a result, the soil-root systems at lower altitudes were characterized by reduced biomass with reduced capacity for soil reinforcement as measured through erosion resistance, soil scour resistance, and shear strength. The correlation analysis indicated that root biomass had a significant positive linear correlation with the enhancement of erosion resistance and scour resistance, and shear strength, respectively.

Conclusions: Roots of the $C$. dactylon community effectively enhanced the stability of riparian shallow soil and riverbank. The fluctuation in water level caused the difference of root growth as the exposed time of plants decreases with the decrease of altitude. The difference of root structure resulted in the variation of the soil-root system in soil conservation and reinforcement.

\section{Introduction}

The riparian plant community is a significant factor influencing the occurrence and progress of riverbed and erosion (Brooks and Lake 2007; Pollen 2007). Riverbanks with a well-established plant community are less prone to bank failure (Hubble 2004; Wang et al. 2009; Greenwood et al. 2004). Restoring and maintaining the riparian plant

\footnotetext{
* Correspondence: fqchen@ctgu.edu.cn

Engineering Research Center of the Ministry of Education for the Three Gorges Reservoir Region's Eco-environment, The China Three Gorges University, Daxue Road, Yichang 443002, People's Republic of China
}

community can conserve soil and control or prevent riverbank failure as well as preserve riverside habitats (Norris et al. 2006; Hubble et al. 2010). The riparian plant community performs its function in soil conservation and slope protection through the cohesion and reinforcement of the soil-root system matrix (Mickovski et al. 2009; Schwarz et al. 2012). The capacity of the soil-root system on soil conservation and reinforcement is characterized by soil erosion resistance, soil scour resistance, and shear strength (De Baets et al. 2006, 2007; Pollen 2007; Genet et al. 2008). A large number of studies showed that the effects of the 
soil-root system on soil conservation and reinforcement were significantly related to the characteristics of plant and soil including plant species, plant age, soil type, and soil moisture (Reubens et al. 2007; Xu and Zeng 2008; Stokes et al. 2009; Fan and Lai 2014). Among these characteristics, root structure and distribution were directly related to the enhancement of the soil-root system on soil conservation (Mickovski and van Beek 2009; Ji et al. 2012; Ghestem et al. 2014). Changes in the spatial distribution of plant community and plant roots caused by environmental changes influence significantly the effects of plant roots on slope stabilization (Cammeraat et al. 2005; Normaniza et al. 2008; Burylo et al. 2012).

The Three Gorges Project, one of the largest water conservancy and hydropower projects in the world, has significantly altered the region's riparian environment by forming $400-\mathrm{km}^{2}$ riparian belts around the reservoir with water-level fluctuation (from 145 to $175 \mathrm{~m}$ ) and the reverse seasonal fluvial pattern (exposure in summer and inundation in winter) (Chen and Xie 2007). The traumatic change of dry and wet cycles causes stresses of riparian plants and leads to the degradation of the plant community. The composition and structure of plant communities degrade and become simple in the particular ecological environment (Chen and Xie 2009; Lu et al. 2010; Liu et al. 2011). The quick and frequent drawdown of water level exacerbates water erosion and scouring (Xu et al. 2009). These changes increase soil erosion, bank collapse, and landslide endangering ecological safety in the reservoir area. Restoring riparian vegetation can effectively improve the ecological environment in the Three Gorges Reservoir region (Wang et al. 2004; Xu et al. 2009). Cynodon dactylon is a common riparian plant species in the Three Gorges Reservoir area (Liu et al. 2011) and has become a dominant species with a strong ability to adapt to flooding and drought since the Three Gorges Project was finished (Chen et al. 2010). In this paper, a field survey and experimental research were conducted to (1) evaluate the differences in root system biomass and other root system characteristics of the C. dactylon community with altitude, (2) evaluate the effect of the root system of the $C$. dactylon community on several soil conservation and soil strength characteristics which are known to have an impact on slope stability, and (3) examine the relationship between root system biomass and these same soil conservation and soil strength characteristics, thereby allowing a consideration of the relationship between water-level fluctuation and the capacity of $C$. dactylon to contribute to slope stability and riverbank protection in the Three Gorges Reservoir area.

\section{Methods}

\section{Field experimental design}

The field experiment was set up on the riparian bank of the Xiangxi River, a branch of the Yangzi River in the Three
Gorges Reservoir region. Five quadrates $\left(10 \times 10 \mathrm{~m}^{2}\right)$ of a natural $C$. dactylon community were set up on a riverbank along an altitude (elevation above sea level) gradient only from 155 to $175 \mathrm{~m}$ at 5-m intervals as the exposed time of plant communities below $155 \mathrm{~m}$ was too short to recover adequately when the field investigation was carried out. The soil was classified as tidal sandy soil derived from river alluvium with sandy loam texture. Five subquadrates $\left(1 \times 1 \mathrm{~m}^{2}\right)$ were arranged randomly in each main quadrate. Plants were sampled randomly in each subquadrate for the measurements of spatial structure and tensile strength of roots. In addition, the soil-root system was sampled using a soil sampler (diameter $8 \mathrm{~cm}$, depth $15 \mathrm{~cm}$ ) in each subquadrate. The samples were wrapped with plastic and brought back for the measurement of soil erosion resistance, soil scour resistance, and shear strength in the laboratory.

\section{Determination of root tensile strength and root system structure}

The Diti method was used to test the tensile strength of roots (Yang et al. 2007):

$$
P=4 F / \pi D^{2}
$$

where $F$ and $D$ represent the maximum tensile resistance and diameter of the section of the root, respectively, which were tested using a stress recorder and vernier caliper in the field. $P$ representing the root tensile strength was calculated according to formula (1). Five plants were sampled randomly in each subquadrate to measure the tensile strength of roots in the field, and another ten plants to measure root length, root surface area, and number of root furcations in the laboratory. Then, the sampled plants were divided into ground and underground parts from the root collar, dried to a constant mass at $60^{\circ} \mathrm{C}$ in an oven, and weighed to test their biomass.

\section{Characterization of the soil-root system in soil conservation and reinforcement}

Enhancement of soil scour resistance of the soil-root system was measured using the method of scouring soil samples with hydraulic flume based on the following calculation (Xu and Zeng 2008; Burylo et al. 2012):

$$
\mathrm{Ev}=\left(C_{1}-C_{2}\right) / C_{2}
$$

where $\mathrm{Ev}$ is the enhancement of root scour resistance of the soil-root system (the increasing multiple in scour resistance is due to root presence). Its value and range depend on root biomass, root texture and distribution of related species, plant growth, and environmental condition. $C_{1}$ and $C_{2}$ represent the scour resistance coefficients of the soil-root system and control sample, respectively. 
The measurement unit of the scour resistance coefficient is the amount of water (L) to flush out $1 \mathrm{~g}$ of saturated sample soil. The scour resistance coefficient was tested using the method described by $\mathrm{Xu}$ and Zeng (2008). Five soil-root system samples and one control sample were tested repeatedly at each altitude gradient. The roots of each sample were separated and dried to a constant mass at $60^{\circ} \mathrm{C}$ in an oven, and weighed to test their biomass for the relationship analysis between scour resistance and root structure.

Enhancement of soil erosion resistance of the soil-root system was measured using the method of collapse resistance in static water and calculated as follows ( $\mathrm{Xu}$ and Zeng 2008; Burylo et al. 2012):

$$
\mathrm{Ce}=\left(V_{1}-V_{2}\right) / V_{2}
$$

where $\mathrm{Ce}$ is the enhancement of erosion resistance of the soil-root system ranging from 0 to $1 . V_{1}$ and $V_{2}$ are the detachment rate of the soil-root system sample and control soil sample, respectively. Detachment rate was measured using the weight of disintegrating water-saturated soil in unit time represented by $V=M / t=\left(M_{1}-M_{2}\right) / t(\mathrm{~g} / \mathrm{min})$. The detachment rate of samples was tested using the method described by Burylo et al. (2012). Five soil-root system samples and one control sample were tested repeatedly at each altitude gradient. The roots of each sample were separated and dried to a constant mass at $60^{\circ} \mathrm{C}$ in an oven, and weighed to test their biomass for the relationship analysis between erosion resistance and root structure.

Soil shear strength of the soil-root system was measured based on the Mohr-Coulomb law (Xu and Zeng 2008; Burylo et al. 2012):

$$
\tau_{\mathrm{f}}=\sigma \tan \varphi+C
$$

where $C$ is the effective soil cohesion $(\mathrm{kPa})$, including the cohesion among soil particles and the cohesion between soil particles and roots; $\sigma$ is the effective stress force that is normal to the slope ( $\mathrm{kPa})$; and $\varphi$ is the effective angle of shear resistance $\left(^{\circ}\right)$. Soil shear resistance indices $(C, \varphi)$ are determined according to the $\tau$ - $\sigma$ curve. Soil shearing stress $(\tau)$ was calculated by the formula $\tau=K R$ and tested using a strain-controlled direct shear apparatus. The quantum ring rate coefficient of determination $(K)$ is set as $2.5 \mathrm{kPa} / 0.01 \mathrm{~mm}$, and the unit of dial test indicator readings $(R)$ was set as $0.01 \mathrm{~mm}$. Each sample of the soil-root system was cut into four cylindrical testing samples (diameter $8 \mathrm{~cm}$, depth $2 \mathrm{~cm}$ ) which was put into a shear box and saturated with water for the determination of shearing stress. Five samples were tested repeatedly at each altitude gradient. The roots of each sample were separated and dried to a constant mass at $60^{\circ} \mathrm{C}$ in an oven, and weighed to test their biomass for the relationship analysis between shear strength and root structure.

\section{Data analysis}

One-way analysis of variance (ANOVA) was performed to determine the structure of roots and the effects of the soil-root system on soil conservation and slope protection. The altitudinal gradient was used as an independent factor, and root structure indexes (root biomass, root length, root area, and number of root furcation) and soil reinforcement indexes (root tensile strength, enhancement of soil erosion resistance, enhancement of soil scour resistance, and shear strength) as dependent factors. The Duncan test method was conducted for multiple comparisons to test the significance level of each parameter among treatments when the main effect was significant. The relationship of spatial distribution between root structure and the performance of the soilroot system in soil conservation and slope protection was uncovered by linear analysis of root biomass with enhancement of soil erosion resistance, enhancement of soil scour resistance, and shear strength, respectively. All analyses were conducted using SPSS software (13.0).

\section{Results}

\section{The spatial structure of roots}

The structure and distribution of roots changed with altitude (Table 1). Root length, root area, number of root furcation, and root biomass of $C$. dactylon plants increased significantly with the increase of altitude $(P<0.05)$ and reached the maximum at an altitude of $175 \mathrm{~m}$. Their root length, number of root furcation, root area, root biomass, and plant biomass at $175 \mathrm{~m}$ increased by $26.6 \%, 121.3 \%$, $166.2 \%, 113.5 \%$, and $207.4 \%$, respectively, compared to those at $155 \mathrm{~m}$. However, the difference was not significant within low altitudes (155 and $160 \mathrm{~m}$ ) and middle upper altitudes $(165,170$, and $175 \mathrm{~m})(P>0.05)$.

\section{Soil enhancement and spatial variation of the soil-root system}

The roots of $C$. dactylon plants had good tensile strength and enhanced effectively the performance of soil in soil reinforcement and slope protection. The average soil detachment of the soil-root system of $C$. dactylon decreased $32.0 \%$ in contrast to the control soil, and the soil scour resistance coefficient and shear strength of the soil-root system increased $315.4 \%$ and $21.1 \%$, respectively (Figure 1).

The tensile strength of roots and performance of the soil-root system in soil conservation and reinforcement changed along with the altitude gradient (Figure 2). The tensile strength, enhancement of soil erosion resistance, enhancement of soil scour resistance, and shear strength of the soil-root system at $175 \mathrm{~m}$ were about $40.39 \%$, 
Table 1 Characteristics of $C$. dactylon's root system at various elevations

\begin{tabular}{lccccc}
\hline Elevation $(\mathbf{m})$ & Root length $(\mathbf{m m})$ & Root area $\left.\mathbf{( c m}^{\mathbf{2}}\right)$ & Number of root furcation & Root biomass (g) & Plant biomass $(\mathbf{g})$ \\
\hline 155 & $65.598 \pm 2.691 \mathrm{~b}$ & $7.970 \pm 0.540 \mathrm{~b}$ & $1,120 \pm 102 \mathrm{~b}$ & $0.052 \pm 0.006 \mathrm{~b}$ & $0.720 \pm 0.100 \mathrm{c}$ \\
160 & $69.634 \pm 3.449 \mathrm{~b}$ & $8.275 \pm 0.849 \mathrm{~b}$ & $1,684 \pm 295 \mathrm{ab}$ & $0.063 \pm 0.009 \mathrm{ab}$ & $0.852 \pm 0.115 \mathrm{c}$ \\
165 & $79.356 \pm 3.190 \mathrm{a}$ & $13.440 \pm 2.519 \mathrm{ab}$ & $1,794 \pm 247 \mathrm{ab}$ & $0.069 \pm 0.021 \mathrm{ab}$ & $1.451 \pm 0.333 \mathrm{bc}$ \\
170 & $80.626 \pm 3.377 \mathrm{a}$ & $13.928 \pm 2.912 \mathrm{ab}$ & $1,945 \pm 387 \mathrm{ab}$ & $0.101 \pm 0.010 \mathrm{ab}$ & $1.849 \pm 0.217 \mathrm{ab}$ \\
175 & $83.033 \pm 3.456 \mathrm{a}$ & $17.638 \pm 2.216 \mathrm{a}$ & $2,981 \pm 523 \mathrm{a}$ & $0.111 \pm 0.015 \mathrm{a}$ & $2.214 \pm 0.280 \mathrm{a}$ \\
Total & $F=5.542 ;$ & $\mathrm{F}=4.073 ;$ & $\mathrm{F}=3.940 ;$ & $\mathrm{F}=3.288 ;$ & $\mathrm{F}=7.830 ;$ \\
& significance $=0.000$ & significance $=0.014$ & significance $=0.016$ & significance $=0.014$ & significance $=0.000$ \\
\hline
\end{tabular}

Values are expressed as mean $\pm \mathrm{SE}$; means followed by the same letter(s) within each column are not significant at $P<0.05$.

$125.29 \%, 374.09 \%$, and $23.84 \%$, respectively, more than those at an altitude of $155 \mathrm{~m}$. The tensile strength of C. dactylon roots was significant among the upper (175 and $170 \mathrm{~m}$ ), middle (160 and $165 \mathrm{~m})$, and middle lower $(155 \mathrm{~m})$ parts $(P<0.01)$, while the internal difference within each part was not significant. The enhancement of soil scour resistance differed significantly between each altitude. The enhancement of soil erosion resistance differed significantly among the upper $(175 \mathrm{~m})$, upper middle (170 and $165 \mathrm{~m}$ ), and middle lower (160 and $155 \mathrm{~m})$ parts $(P<0.01)$. The shear strength differed significantly among the upper middle $(175,170$, and $165 \mathrm{~m})$ and middle lower parts $(160$ and $155 \mathrm{~m})(P<0.01)$, while the internal difference within each part was not significant. Soil indicators as gradients increased due to the soil-root systems at high gradients which had more exposure time to develop.

Relationship between root biomass and soil enhancement of the soil-root system

The tensile strength of roots and enhancement of soil scour resistance, and the enhancement of soil erosion resistance and shear strength of the soil-root system had a non-linear correlation and rectilinear correlation with root biomass, respectively (Figure 3 ). The enhancement of soil erosion resistance, shear strength, enhancement of soil scour resistance of the soil-root system, and tensile strength of roots increased with the increase of root biomass. However, the tensile strength of roots and enhancement of soil scour resistance of the soil-root system increased slowly when root biomass of each seedling was over $0.10 \mathrm{~g}$ and root biomass of the soil-root system was over $1.2 \mathrm{~g} / \mathrm{cm}^{3}$. It indicated that increase of biomass promoted the performance of the soil-root system in soil conservation and slope reinforcement.

\section{Discussion}

\section{Root enhancement}

Roots of shrub and herbaceous plants usually concentrate within a $30-\mathrm{cm}$ soil layer where much soil erosion usually takes place (Ding et al. 2002); therefore, a wellgrown plant community can effectively enhance soil reinforcement and slope reinforcement by increasing the soil erosion resistance, soil scour resistance, and
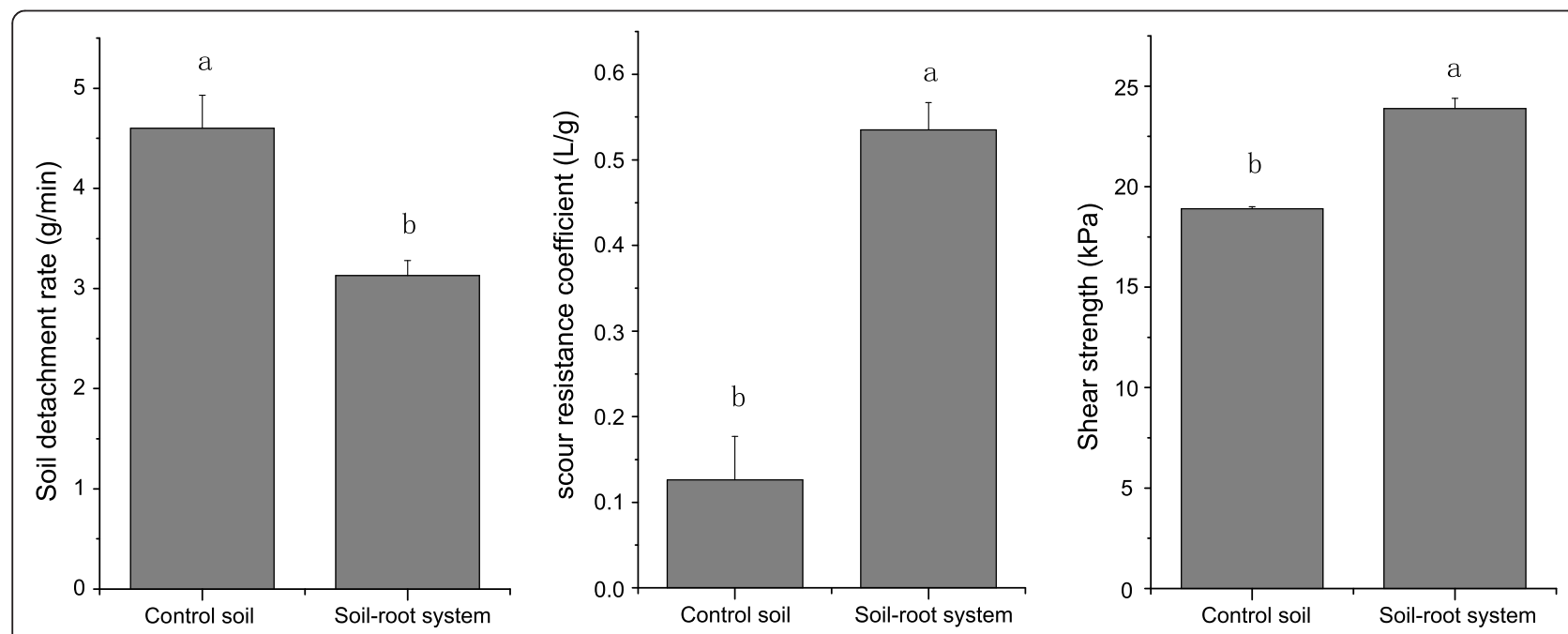

Figure 1 Effects of soil-root system (C. dactylon) on soil detachment rate, scour resistance coefficient, and shear strength. 


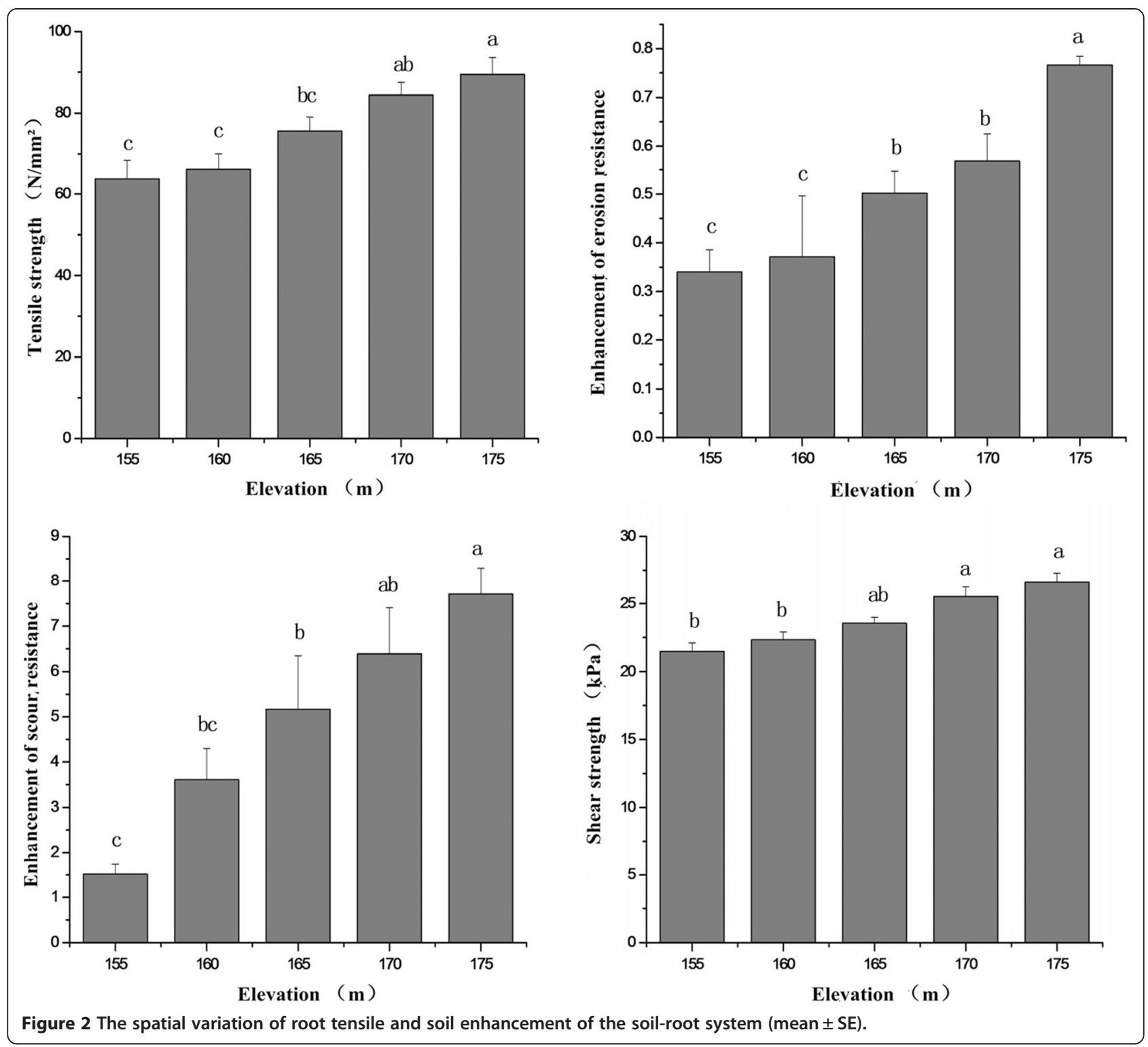

shear strength of riparian soil through cohesion and reinforcement of the root system (Hubble et al. 2010; Comino and Druetta 2010; Schwarz et al. 2010). The soil-root system's theory is that the soil-root system with a spatial distribution and structure can increase the shear strength of soil through associative root networks which reinforce soil layers by towing obliquely and anchoring vertically (Schmidt et al. 2001; Stokes et al. 2008; Fan and $\mathrm{Su}$ 2008). Plant roots can also affect physical and chemical properties of soil related to soil erosion which further promote soil stability (Gyssels et al. 2005). The enhancement of plant roots differs significantly for plant species (Docker and Hubble 2008; Abdi et al. 2009; Zhang et al. 2014). Xu et al. (2011) reported that Triarrherca sacchariflora had the best enhancement on anti-scouring among the five species they tested. Our study found that C. dactylon performed well for enhancement of shallow soil conservation and riverbank stability. Soil erosion resistance, soil scour resistance, and shear strength of the soil-root system were significantly improved with C. dactylon.

\section{Spatial variation of root enhancement}

The spatial dynamics of the root system was related to the interaction between plant roots and soil, making the effects of plant roots on soil conservation and slope protection change with the spatial dynamics of the root system and ecological environment (Stokes et al. 2008). 


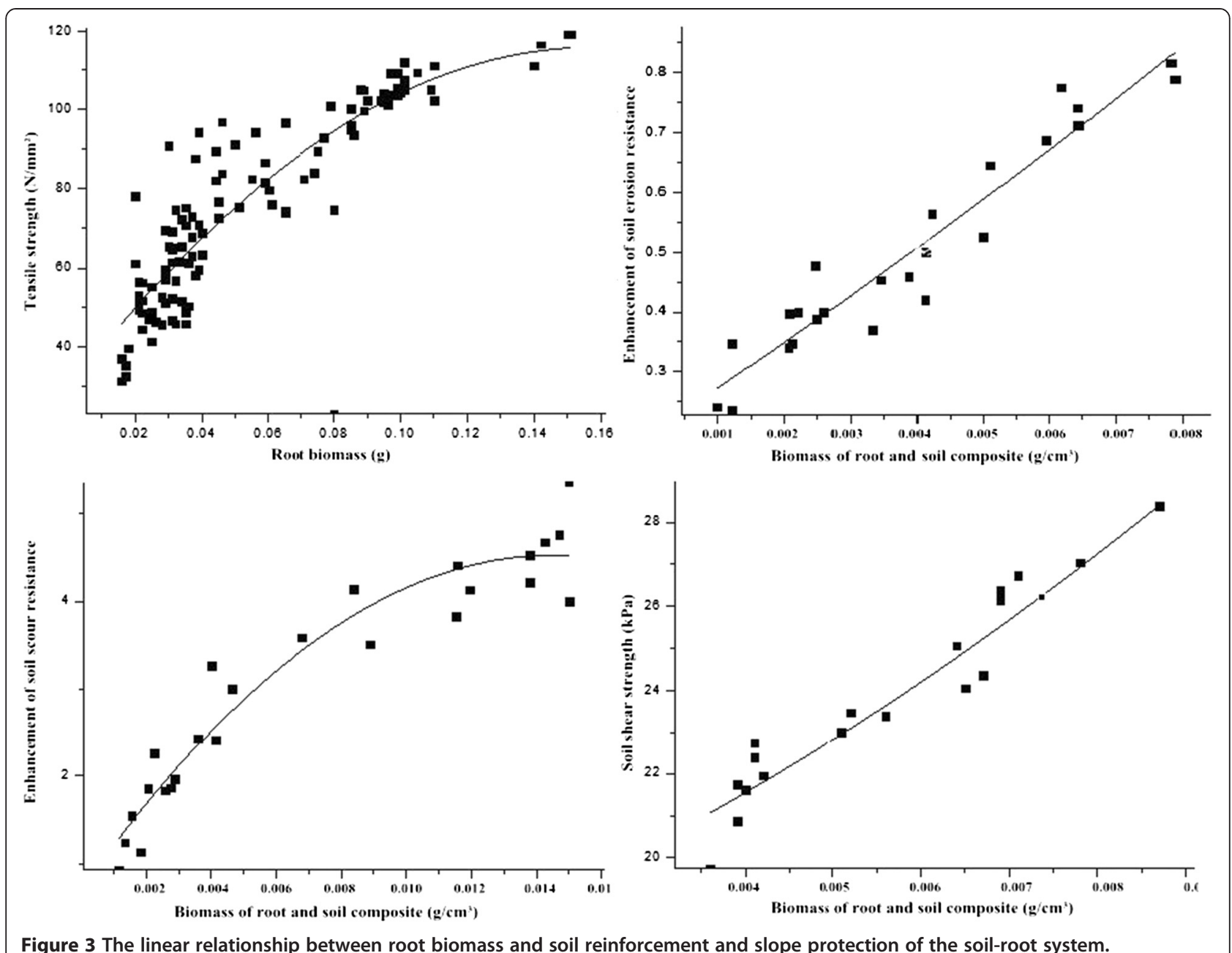

Figure 3 The linear relationship between root biomass and soil reinforcement and slope protection of the soil-root system.

The fluvial pattern in the Three Gorges Reservoir area has changed from summer inundation with winter exposure to summer exposure with winter inundation (a reverse seasonal fluctuation) for electricity production and flood control. The water level reaches $175 \mathrm{~m}$ from mid-October to January, then gradually declines to $160 \mathrm{~m}$ in March and April, and finally to $145 \mathrm{~m}$ from June to October. The water drawdown significantly affected the growing period of the $C$. dactylon community and resulted in the spatial difference of root growth and distribution. Both Cazzuffi et al. (2006) and Tosi (2007) reported that the spatial structure of riparian plants changed with the change of ecological environment during their growth and development which further induced the change of the soil-root system in soil conservation and slope protection. The distribution of root length, root area, root bifurcation number, and root biomass of $C$. dactylon showed significant differences among altitudes, and increased with increasing altitude. Plants at $175 \mathrm{~m}$ grow best, as this altitude has extended the drawdown period for plants to grow. The linear analysis of root biomass with enhancement indexes suggested that the enhancement of the soil-root system on soil conservation and slope stability increased with the increasing root biomass. The spatial variations of root biomass make the performance of soil conservation and reinforcement of the soil-root system change along with altitude gradient. Therefore, it can be concluded that this change was related to amplitude and reverse seasonal fluctuation in the Three Gorges Reservoir region.

\section{Conclusions}

The results of our study showed that the roots of the C. dactylon community effectively enhanced the stability of riparian shallow soil and riverbank. The tensile strength, enhancement of soil erosion resistance, enhancement of soil scour resistance, and shear strength of the soil-root system of $C$. dactylon were significantly higher than those of the control soil. However, the enhancement effect of $C$. dactylon roots changed along 
with the riparian altitude gradient in the Three Gorges Reservoir area. The tensile strength, enhancement of soil erosion resistance, enhancement of soil scour resistance, and shear strength of the soil-root system at $175 \mathrm{~m}$ were about $40.39 \%, 125.29 \%, 374.09 \%$, and $23.84 \%$, respectively, more than those at an altitude of $155 \mathrm{~m}$. The biomass of soil-root systems was related significantly with the soil erosion resistance, soil scour resistance, and shear strength. The spatial variation of roots made the performance difference of the soil-root systems. The fluctuation in water level caused the difference of root biomass and structure, as the exposed time of plants decreased with the decrease of altitude in the Three Gorges Reservoir area. The difference of root biomass and structure resulted in the variation of the soil-root system in soil conservation and reinforcement.

The riverbank in the Three Gorges Reservoir covers $400 \mathrm{~km}^{2}$ with a length of over $2,000 \mathrm{~km}$. The change of fluvial pattern has caused the degradation of vegetation and reduction of the soil-root system in soil conservation and slope reinforcement. Most riparian shrub and herb species disappear as they cannot adapt to the new fluvial pattern (Chen and Xie 2010; Lu et al. 2010). The vegetation degrades toward the annual herb community in the Three Gorges Reservoir area. The wave and fluctuation of water level caused frequent soil slide and collapse (Xu et al. 2009). The riverbank is facing the danger of becoming 'bare bald' like most other reservoirs of large water conservancy and hydropower projects. Riparian plant species selection for riverbank restoration in the Three Gorges Reservoir area should have not only a good ability in soil conservation and reinforcement but also a good adaptation to the new fluvial pattern. C. dactylon with good adaptation to flooding and the ability of clonal propagation is one of the few perennial herbs to adapt to the changed environment (Chen et al. 2010). Restoring the $C$. dactylon community and taking full advantage of its effect on soil conservation and slope protection can effectively reduce soil erosion and enhance riverbank stability.

\section{Competing interests}

The authors declare that they have no competing interests.

\section{Authors' contributions}

$J Z, M Z$ and JW were the major persons involved in the field and laboratory experiments. JZ and FC have analyzed and interpreted the experimental data and primarily drafted the manuscript. All authors approved the final draft of this manuscript.

\section{Acknowledgements}

We would like to thank Professor Yinghua Huang and Yongchong Li for their patience in refining the manuscript. This work is supported by a National Key Technology R \& D Program of China (2012BAC06B02-04).

Received: 20 July 2014 Accepted: 24 December 2014

Published online: 31 January 2015

\section{References}

Abdi E, Majnounian B, Rahimi H, Zobeiri M (2009) Distribution and tensile strength of Hornbeam (Carpinus betulus) roots growing on slopes of Caspian Forests, Iran. J Forest Res 20:105-110

Brooks SS, Lake PS (2007) River restoration in Victoria, Australia: change is in the wind and none too soon. Restor Ecol 15:584-591

Burylo M, Rey F, Mathys N, Dutoit T (2012) Plant root traits affecting the resistance of soils to concentrated flow erosion. Earth Surf Proc Land 37:1463-1470

Cammeraat E, van Beek R, Kooijman A (2005) Vegetation succession and its consequences for slope stability in SE Spain. Plant Soil 278:135-147

Cazzuffi D, Corneo A, Crippa E (2006) Slope stabilization by perennial 'gramineae' in Southern Italy: plant growth and temporal performance. Geotech Geol Eng 24:429-447

Chen F, Xie Z (2007) Reproductive allocation, seed dispersal and germination of Myricaria laxiflora, an endangered species in the Three Gorges Reservoir area. Plant Ecol 191:67-75

Chen F, Xie Z (2009) Survival and growth responses of Myricaria laxiflora seedlings to summer flooding. Aquat Bot 90:333-338

Chen F, Huang Y, Fan D, Xie Z (2010) Ecological response of vegetative propagule of Cynodon dactylon to simulated summer flooding. Guihaia 30:488-492 (in Chinese with English abstract)

Comino E, Druetta A (2010) The effect of Poaceae roots on the shear strength of soils in the Italian alpine environment. Soil Till Res 106:194-201

De Baets S, Poesen J, Gyssels G, Kapen A (2006) Effects of grass roots on the erodibility of top soils during concentrated flow erosion. Geophys J Roy Astron Soc 76:54-67

De Baets S, Poesen J, Knapen A, Gonzáles Barberá G, Navarro JA (2007) Root characteristics of representative Mediterranean plant species and their erosion-reducing potential during concentrated runoff. Plant Soil 294:169-183

Ding J, Wang Z, Chen X, Zhang R (2002) Study on increased effect of soil anticourability by root system of forest land in red soil hilly region. I Soil Water Conserv 16:9-12 (in Chinese with English abstract)

Docker BB, Hubble TCT (2008) Quantifying the enhanced soil shear strength beneath four riparian tree species. Geophys J Roy Astron Soc 100:400-418

Fan C, Lai Y (2014) Influence of the spatial layout of vegetation on the stability of slopes. Plant Soil 377:83-95

Fan C, Su C (2008) Role of roots in the shear strength of root-reinforced soils with high moisture content. Ecol Eng 33:157-166

Genet M, Kokutse N, Stokes A, Fourcaud T, Cai X, Ji J, Mickovski S (2008) Root reinforcement in plantations of Cryptomeria japonica D. Don: effect of tree age and stand structure on slope stability. Forest Ecol Manag 256:1517-1526

Ghestem M, Veylon G, Bernard A, Vanel Q, Stokes A (2014) Influence of plant root system morphology and architectural traits on soil shear resistance. Plant Soil 377:43-61

Greenwood JR, Norris JE, Wint J (2004) Assessing the contribution of vegetation to slope stability. Proc Inst Civil EngGeotech Eng 157(4):199-207

Gyssels G, Poesen J, Bochet E, Li Y (2005) Impact of plant roots on the resistance of soils to erosion by water: a review. Prog Phys Geog 29:189-217

Hubble TCT (2004) Slope stability analysis of potential bank failure as a result of toe erosion on weir-impounded lakes: an example from the Nepean River, New SouthWales Australia. Mar Freshwater Res 55:57-65

Hubble TCT, Dockera BB, Rutherfurd ID (2010) The role of riparian trees in maintaining riverbank stability: a review of Australian experience and practice. Ecol Eng 36:292-304

Ji J, Kokutse N, Genet M, Fourcaud T, Zhang Z (2012) Effect of spatial variation of tree root characteristics on slope stability. A case study on Black Locust (Robinia pseudoacacia) and Arborvitae (Platycladus orientalis) stands on the Loess Plateau, China. Catena 92:139-154

Liu W, Yang F, Wang J, Wang Y (2011) Plant species dynamics distribution in the water-level-fluctuating zone of the main stream and bay of the Three Gorges Reservoir. J Wuhan Bot Res 29:296-306 (in Chinese with English abstract)

Lu Z, Li L, Huang H, Tao M, Zhang Q, Jiang Q, Jiang M (2010) Preliminary effects of impounding on vegetation in drawdown zone of the Three Gorges Reservoir region. J Wuhan Bot Res 28:303-314 (in Chinese with English abstract)

Mickovski SB, van Beek LPH (2009) Root morphology and effects on soil reinforcement and slope stability of young vetiver (Vetiveria zizanioides) plants grown in semi-arid climate. Plant Soil 324:43-56 
Mickovski SB, Hallett PD, Bransbyd MF, Daviese MCR, Sonnenbergd R, Bengough AG (2009) Mechanical reinforcement of soil by willow roots: impacts of root properties and root failure mechanism. Soil Sci Soc Am J 73:1276-1285

Normaniza O, Faisal HA, Barakbah SS (2008) Engineering properties of Leucaena leucocephala for prevention of slope failure. Ecol Eng 32:215-221

Norris JE, Cammeraat LH, Stokes A, Spanos I (2006) The use of vegetation to improve slope stability. Geotech Geol Eng 24:427-428

Pollen N (2007) Temporal and spatial variability in root reinforcement of stream banks: accounting for soil shear strength and moisture. Catena 69:197-205

Reubens B, Poesen J, Danjon F, Geudens G, Muys B (2007) The role of fine and coarse roots in shallow slope stability and soil erosion control with a focus on root system architecture: a review. Trees 21:385-402

Schmidt KM, Roering JJ, Stock JD, Dietrich WE, Montgomery DR, Schaub T (2001) The variability of root cohesion as an influence on shallow landslide susceptibility in the Oregon Coast Range. Can Geotech J 38:995-1024

Schwarz M, Pretic F, Giadrossichc F, Lehmannb P, Orb D (2010) Quantifying the role of vegetation in slope stability: a case study in Tuscany (Italy). Ecol Eng 36:285-291

Schwarz M, Cohen D, Orb D (2012) Spatial characterization of root reinforcement at stand scale: theory and case study. Geophys J Roy Astron Soc 171-172:190-200

Stokes A, Norris JE, van Beek LPH, Bogaard T, Cammeraat E, Mickovski SB, Di lorio A, Fourcaud T (2008) How vegetation reinforces soil on slopes. In: Slope stability and erosion control: ecotechnological solutions. Springer, Netherlands

Stokes A, Atger C, Bengough AG, Fourcaud T, Sidle RC (2009) Desirable plant root traits for protecting natural and engineered slopes against landslides. Plant Soil 324:1-30

Tosi M (2007) Root tensile strength relationships and their slope stability implications of three shrub species in the Northern Apennines (Italy). Geophys J Roy Astron Soc 87:268-283

Wang Y, Wu J, Huang H, Liu S (2004) Quantitative analysis of plant communities in water-level-fluctuation zone within Three Gorges Reservoir Area of Changjiang River. J Wuhan Bot Res 22:307-314 (in Chinese with English abstract)

Wang J, Ye F, Chen F (2009) The function of vegetation on landslide stability: the reasons caused the Qianjiangping landslide in Three Gorges reservoir area. In: 4th international Yellow River forum on ecological civilization and river ethics (II)., pp 136-142

Xu S, Zeng B (2008) Enhancement effects of 5 flooding-tolerant species' roots on soil anti-erodibility in Three Gorges reservoir region. J Soil Water Conserv 22:13-22 (in Chinese)

Xu Q, Fu W, Sun L, Tan B, Wang X (2009) Study on soil anti-erodibility for the water-level-fluctuating zone in the Three Gorges reservoir area. Res Soil Water Conserv 16:13-18 (in Chinese with English abstract)

Xu S, Zeng B, Lei S, Su X (2011) Root features of several flooding-tolerant plants and their roles in enhancing anti-erodibility of the soil in Three Gorges reservoir region. Acta Pedol Sin 22:13-18 (in Chinese with English abstract)

Yang W, Liu X, Chen L, Song W (2007) The construction and application of strength measurement curve of Abies fabricroot system with pull-out method. Res Soil Water Conserv 14:197-199 (in Chinese)

Zhang X, Yu GQ, Li ZB, Li P (2014) Experimental study on slope runoff, erosion and sediment under different vegetation types. Water Resour Manage 28:2415-2433

\section{Submit your manuscript to a SpringerOpen ${ }^{\odot}$ journal and benefit from:}

- Convenient online submission

- Rigorous peer review

- Immediate publication on acceptance

- Open access: articles freely available online

- High visibility within the field

- Retaining the copyright to your article

Submit your next manuscript at $>$ springeropen.com 